\title{
INVESTIGATION OF COMPOSITION AND STRUCTURE OF WELD METAL OF Kh20N9G2B TYPE MADE IN WET UNDERWATER WELDING
}

\author{
K.A. YUSHCHENKO, A.V. BULAT, N.Yu. KAKHOVSKY, \\ V.I. SAMOJLENKO, S.Yu. MAKSIMOV and S.G. GRIGORENKO \\ E.O. Paton Electric Welding Institute, NASU \\ 11 Bozhenko Str., 03680, Kiev, Ukraine. E-mail: office@paton.kiev.ua
}

\begin{abstract}
The paper gives the results of investigations of variation of weld metal composition and structure in coated-electrode wet underwater arc welding of $12 \mathrm{Kh} 18 \mathrm{~N} 10 \mathrm{~T}$ steel. It is shown that unlike welding in air, in underwater welding the content of oxygen and hydrogen increases in the weld metal with simultaneous lowering of the quantity of ferritizers. Weld metal structure is characterized by presence of predominantly columnar crystallites, decreased fraction of grain-boundary $\delta$-ferrite and increased volume fraction of oxide non-metallic inclusions, the quantity of which with 0.10 to $1.25 \mu \mathrm{m}$ dispersion rises 1.5 to 2 times. 14 Ref., 4 Tables, 2 Figures.
\end{abstract}

Key words: wet underwater welding, 12Kh18N10T steel, coated electrodes, weld metal, composition, structure, non-metallic inclusions

Coated-electrode underwater arc welding has been applied for almost 80 years in repair-reconditioning operations on various-purpose vessels and hydraulic facilities from low-carbon and lowalloyed steels [1-4]. Its features have been quite comprehensively studied [5-9] that allowed development of efficient technologies and specialized welding consumables [10-13].

Over the recent years the task of improvement of the technology of repair of damage of $12 \mathrm{Kh} 18 \mathrm{~N} 10 \mathrm{~T}$ steel lining of concrete pools for storage of NPP spent fuel elements became ur- gent. In order to solve this problem, it is intended to eliminate the operations of water pumping down and pool deactivation, and to perform repair by the method of coated-electrode wet underwater arc welding (furtheron referred to as underwater welding). However, the features of underwater welding of $12 \mathrm{Kh} 18 \mathrm{~N} 10 \mathrm{~T}$ steel have not been studied well enough; moreover, specialpurpose electrodes have not yet been developed.

At the preliminary stage of such electrode development, the influence of welding conditions on weld composition and structure had to be studied. $3 \mathrm{~mm}$ test electrodes of E-08Kh20N9G2B type were manufactured for this purpose, the characteristics of which are given in Table 1. It

Table 1. Test electrode characteristics and welding modes

\begin{tabular}{|c|c|c|c|c|c|c|c|}
\hline \multirow[b]{2}{*}{$\begin{array}{c}\text { Electrode } \\
\text { designation }\end{array}$} & \multicolumn{3}{|c|}{ Test electrode characteristics ${ }^{*}$} & \multicolumn{3}{|c|}{ Welding conditions and mode } & \multirow[b]{2}{*}{$\begin{array}{c}\text { Sample (section) } \\
\text { number }\end{array}$} \\
\hline & $\begin{array}{c}\text { Total content of } \\
\mathrm{CaF}_{2} \text { and } \mathrm{TiO}_{2} \\
\text { in the coating } \\
\%\end{array}$ & $\begin{array}{c}\mathrm{CaF}_{2} \text { and } \mathrm{TiO}_{2} \\
\text { ratio in the } \\
\text { coating }\end{array}$ & $\begin{array}{c}\text { Electrode } \\
\text { diameter, } \mathrm{mm}\end{array}$ & Medium & $I_{\mathrm{w}}^{\mathrm{av}}, \mathrm{A}$ & $U_{\mathrm{a}}^{\mathrm{av}}, \mathrm{V}$ & \\
\hline \multirow[t]{2}{*}{ K-1 } & \multirow[t]{2}{*}{56} & \multirow[t]{2}{*}{$1: 2$} & \multirow[t]{2}{*}{1.6} & Air & 118.8 & 24.3 & 1 \\
\hline & & & & Water & 115.7 & 26.3 & 4 \\
\hline \multirow[t]{2}{*}{$\mathrm{K}-2$} & \multirow[t]{2}{*}{56} & \multirow[t]{2}{*}{$3: 1$} & \multirow[t]{2}{*}{1.6} & Air & 119.3 & 24.2 & 2 \\
\hline & & & & Water & 111.3 & 27.4 & 5 \\
\hline \multirow[t]{2}{*}{$\mathrm{K}-3$} & \multirow[t]{2}{*}{56} & \multirow[t]{2}{*}{$3: 1$} & \multirow[t]{2}{*}{1.8} & Air & 113.4 & 25.5 & 3 \\
\hline & & & & Water & 108.5 & 28.5 & 6 \\
\hline
\end{tabular}


Table 2. Composition of weld metal

\begin{tabular}{|c|c|c|c|c|c|c|c|}
\hline \multirow{2}{*}{ Sample number } & \multicolumn{7}{|c|}{ Content, wt.\% } \\
\hline & $\mathrm{Cr}$ & $\mathrm{Ni}$ & $\mathrm{Mn}$ & $\mathrm{Nb}$ & $\mathrm{Si}$ & $\mathrm{O}$ & $\mathrm{H}$ \\
\hline 1 & 21.3 & 10.8 & 2.0 & 1.0 & 1.2 & 0.059 & 0.0027 \\
\hline 4 & 20.0 & 10.8 & 1.5 & 0.9 & 0.9 & 0.071 & 0.0047 \\
\hline 2 & 21.2 & 10.6 & 2.5 & 1.0 & 1.2 & 0.044 & 0.0019 \\
\hline 5 & 21.0 & 10.9 & 2.0 & 0.7 & 0.8 & 0.061 & 0.0040 \\
\hline 3 & 21.2 & 9.7 & 2.4 & 1.0 & 1.3 & 0.049 & 0.0014 \\
\hline 6 & 21.4 & 10.4 & 2.3 & 0.9 & 1.0 & 0.066 & 0.0029 \\
\hline
\end{tabular}

Table 3. Characteristics of structure of weld metal and HAZ

\begin{tabular}{|c|c|c|c|c|c|c|}
\hline \multirow{2}{*}{ Sample number } & \multicolumn{4}{|c|}{ Weld metal } & \multicolumn{2}{|c|}{ HAZ metal } \\
\hline & $\begin{array}{l}\text { Average diameter } \\
\text { of } \gamma \text {-cells, } \mu \mathrm{m}\end{array}$ & $\begin{array}{c}\text { Dendrite } \\
\text { parameter, } \mu \mathrm{m}\end{array}$ & $\begin{array}{l}\text { Fraction of } \\
\delta \text {-ferrite, \% }\end{array}$ & $\begin{array}{l}\text { NMI volume } \\
\text { fraction }{ }^{*}, \%\end{array}$ & Grain size number & $\begin{array}{l}\text { Fraction of } \\
\delta \text {-ferrite, \% }\end{array}$ \\
\hline 1 & 10 & $10-12$ & $5.2-8.0$ & 0.22 & 5 & $1.5-2.0$ \\
\hline 4 & 10 & $15-25$ & $5-6$ & 0.42 & 6 & $1.0-1.5$ \\
\hline 2 & $5-7$ & $7-10$ & $9.0-10.5$ & 0.13 & 6 & $1.0-1.5$ \\
\hline 5 & $5-7$ & $20-25$ & $8-9$ & 0.29 & 6 & $1.0-2.0$ \\
\hline 3 & $5-7$ & $10-12$ & $9-12$ & 0.19 & 5 & $1.0-1.5$ \\
\hline 6 & $5-7$ & $15-20$ & $8-11$ & 0.33 & 6 & $1.5-2.0$ \\
\hline
\end{tabular}

should be further noted that in order to limit the oxidizing impact of carbon dioxide gas, as well as weld metal hydrogenation, marble content in the coatings was limited to $16 \%$. Moreover, to evaluate the possibility of screening of electrode metal drops from direct oxidizing and hydrogenating effect of water, K-3 electrodes were made, which differ from K-2 electrodes just by coating diameter.

K-1-K-3 electrodes at DCRP supplied from Kemppi PS-500 inverter at unchanged welding mode settings were used to make rigid butt joints

Table 4. Hardness of weld metal, HAZ and base metal

\begin{tabular}{|c|c|c|c|c||}
\hline \multirow{2}{*}{$\begin{array}{c}\text { Sample } \\
\text { number }\end{array}$} & HV0.1, MPa & HRA & \multicolumn{2}{|c||}{ HRA } \\
\cline { 2 - 5 } & \multicolumn{2}{|c|}{ Weld metal } & HAZ & Base metal \\
\hline 1 & $\frac{2100-2130}{2110}$ & $\frac{53.0-55.0}{54.1}$ & $\frac{52.5-54.5}{53.5}$ & $\frac{50.5-54.5}{52.6}$ \\
\hline 4 & $\frac{2130-2180}{2146}$ & $\frac{52.5-55.0}{53.8}$ & $\frac{53.0-54.0}{53.5}$ & $\frac{49.0-53.0}{50.3}$ \\
\hline 2 & $\frac{2190-2210}{2203}$ & $\frac{52.0-54.0}{53.2}$ & $\frac{53.0-53.5}{53.2}$ & $\frac{49.0-53.0}{50.6}$ \\
\hline 5 & $\frac{2190-2360}{2253}$ & $\frac{53.5-54.0}{53.8}$ & $\frac{54.0-56.0}{54.8}$ & $\frac{51.0-52.5}{51.5}$ \\
\hline 3 & $\frac{2100-2210}{2136}$ & $\frac{55.0-55.5}{55.1}$ & $\frac{53.0-55.0}{54.0}$ & $\frac{51.0-54.0}{52.6}$ \\
\hline 6 & $\frac{2180-2300}{2253}$ & $\frac{54.0-56.0}{54.8}$ & $\frac{53.0-55.5}{54.5}$ & $\frac{51.0-53.0}{52.0}$ \\
\hline
\end{tabular}

of plates from $12 \mathrm{Kh} 18 \mathrm{~N} 10 \mathrm{~T}$ steel (321) in air and under the water at about $0.5 \mathrm{~m}$ depth. Singlelayer deposits on plates of the same steel were made in a similar fashion. Welding process analyzer ASP-19 was used to determine electric characteristics of arcing - mean-root-square values of $I_{\mathrm{w}}^{\mathrm{av}}$ and $U_{\mathrm{a}}^{\mathrm{av}}$. Samples 1-6 (sections) were cut out of the respective welded joints and deposits. Alloying element content in welds (in their middle part) was determined by the method of emission spectrum analysis with application of the LOMO spectrometer DFS-36, and that of oxygen and hydrogen was determined by the method of restorative melting in carrier gas flow of cylindrical samples (cut out of weld central part) in the LECO units RO-316 and RH-3. Derived results are given in Table 2 .

Microscope Neophot-32 fitted with digital camera Olympus was used to study the structure of welds and HAZ, as well as take photos of non-metallic inclusions (NMI). Ferrite phase fraction was determined by Ferritgehaltmesser 1.053 ferritometer. Weld metal and HAZ microstructure was revealed by electrolytic etching in $20 \%$ water solution of ammonium sulphide. Results of investigation of weld structure are generalized in Table 3.

Vickers hardness (100 g load) of weld metal was measured using the LECO hardness meter 

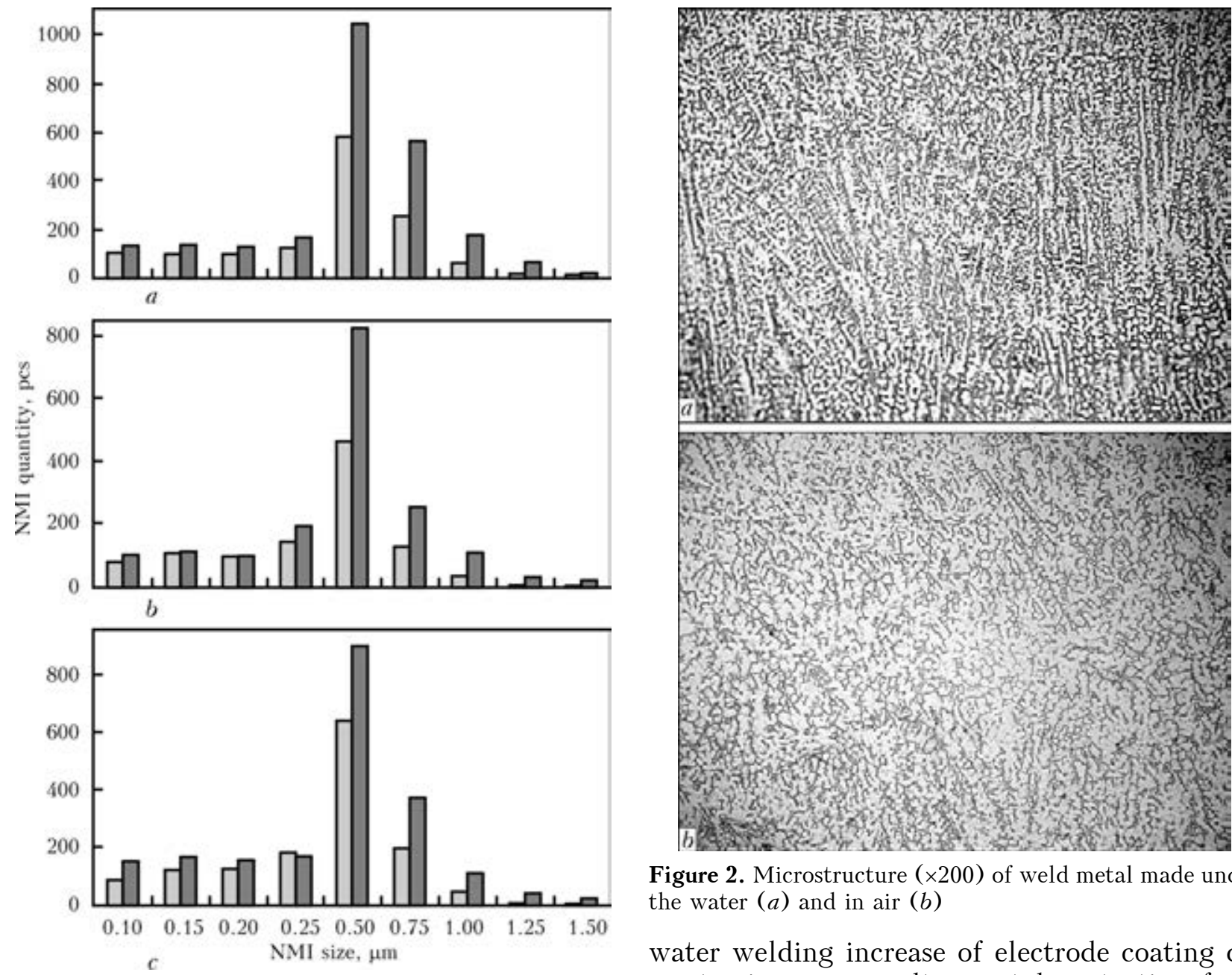

Figure 2. Microstructure $(\times 200)$ of weld metal made under the water $(a)$ and in air $(b)$

water welding increase of electrode coating diameter improves molten metal protection from

Figure 1. Influence of conditions of welding in air (light coloured bars) and in water (dark-coloured) on the quantity of NMI in welds made with electrodes K1 $(a), \mathrm{K}-2(b)$ and $\mathrm{K}-3(c)$

M-400, and Rockwell hardness (60 g load) of weld metal, HAZ and base metal was determined by hardness meter TK-2M. Obtained results are given in Table 4.

According to obtained data (see Table 1) increase of $\mathrm{CaF}_{2} / \mathrm{TiO}_{2}$ ratio in electrode coating, both in welding under the water and in air, leads to lowering of oxygen and hydrogen content in weld metal, that is due to increase of partial pressure of fluorides in the arc atmosphere, lowering of oxygen amount and hydrogen binding into hydrogen fluoride. At other conditions being equal, increase of electrode coating diameter (K2 and K-3 electrodes) causes increase of oxygen and lowering of hydrogen content in weld metal. Such a situation is attributable to the fact that electrode coating and the formed slag in any case have an oxidizing impact on weld metal. Therefore, increase of the amount of remelted coating (slag) at unchanged amount of metal being melted leads to increase of its oxygen content [14]. Moreover, under the conditions of underwater penetration: at the drop stage - due to increase of the depth of the crate from surfacemelted coating at electrode tip (screening), and at the pool stage - due to increasing amount of slag. As a result of summary action of these factors, hydrogen content in the metal decreases.

Molten metal saturation with oxygen in underwater welding and its interaction with deoxidizing elements leads to increase of NMI volume fraction in weld metal (see Table 3 ). Here, quantity of NMI of 0.50 to $1.24 \mu \mathrm{m}$ size increases (Figure 1). Quantity of NMI of more than $1.25 \mu \mathrm{m}$ size in all the studied samples practically did not change and was equal to 8 to $10 \%$ of their total quantity, and volume fraction of NMI of $4.7-10 \mu \mathrm{m}$ size remained within $53-67 \%$ of NMI total volume.

Results of structural investigations (see Table 3) showed that in welds made under the water (sections 4-6), compared to those made in air $(1-3)$, fraction of grain boundary $\delta$-ferrite becomes smaller. In our opinion, this is due to oxidation of ferritizers (silicon, niobium and chromium), having a higher affinity to oxygen than nickel and iron. A characteristic feature of welds, made under the water, is predomination of co- 
lumnar crystallites in their structure (Figure 2, $a)$, whereas for welds made in air, this is prevalence of cellular crystallites (Figure $2, b$ ). In the case of underwater welding, dendrite parameter rises almost 1.5-2 times (see Table 3 ) at unchanged size of austenite cells, that is indicative of development of dendritic axes of second order and expansion of temperature interval of weld metal solidification. At application of all the test electrodes fraction of $\delta$-ferrite and austenite grain size number remained constant, irrespective of welding conditions (see Table 3 ).

According to the results of measurement of weld metal Vickers hardness (see Table 4), in samples welded under the water (4-6) hardness is somewhat higher than in those welded in air (1-3). However, Rockwell hardness measurements did not confirm such changes and showed that in all the studied samples $H R A$ is minimum in base metal and is higher in HAZ and weld metal; here hardness values in the HAZ and weld metal practically do not differ. Such an increase of hardness, compared to base metal, is, most probably, due to plastic deformation localizing in these zones during welding.

\section{Conclusions}

1. At all other conditions being equal, the characteristic features of welds made under the water, compared to those made in air, are their higher content of oxygen (by 1.2 to 1.4 times) and hydrogen (by 1.7 to 2.1 times); lower content of ferritizers (silicon, niobium, chromium); 1.7 to 2.2 times increased volume fraction and quantity of oxide NMI; prevalence of columnar crystallites in their structure at a smaller fraction of grain boundary $\delta$-ferrite.

2. Increase of $\mathrm{CaF}_{2}$ and $\mathrm{TiO}_{2}$ ratio in electrode coating, as well as electrode diameter under the conditions of underweater welding, allows lowering by approximately 1.5 times hydrogen content in weld metal, that is attributable to increase of partial pressure of fluorides in the arc atmosphere and molten metal screening from water impact by a crate from electrode coating with increased content of forming slag.

3 . Both in welding under the water and in air, increase of electrode coating diameter increases oxygen concentration in weld metal, that is due to increase of oxidizing action of electrode coating and slag on weld metal.

1. Khrenov, K.K., Yarkho, V.I. (1940) Technology of arc electric welding. Moscow; Leningrad: Mashinostroenie.

2. Khrenov, K.K. (1946) Underwater electric welding and cutting of metals. Moscow: Min. VS SSSR.

3. Avilov, T.I. (1958) Investigation of underwater arc welding process. Svarochn. Proizvodstvo, 5, 12-14.

4. Savich, I.M., Smolyarko, V.B., Kamyshev, M.A. (1976) Technology and equipment for semiautomatic underwater welding of metal structures. Nefteprom. Stroitelstvo, 1, 10-11.

5. Madatov, N.M. (1965) About properties of vapor-gas bubble around arc in underwater welding. Avtomatich. Svarka, 12, 25-29.

6. Kononenko, V.Ya. (2006) Technologies of underwater welding and cutting. Kiev: PWI.

7. Reynolds, T.J. (2010) Service history of wet welded repairs and modifications. In: Proc. of Int. Workshop on State-of-the-Art Science and Reliability of Underwater Welding and Inspection Technology (Houston, USA, Nov. 17-19, 2010), 31-64.

8. Logunov, K.V. (2003) Underwater welding and cutting of metals. St.-Petersburg: Kosta.

9. Kononenko, V.Ya. (2011) Underwater welding and cutting. Kiev: Ekotekhnologiya.

10. Savich, I.M. (1969) Underwater flux-cored wire welding. Avtomatich. Svarka, 10, 70-71.

11. Maksimov, S.Yu. (1998) New electrodes for underwater wet welding in all positions. In: Proc. of 1st Int. Conf. of CIS Countries on State-of-the-Art and Prospects of Development of Welding Consumables in CIS Countries, 125-128.

12. Murzin, V.V., Murzin, V.T., Russo, V.L. et al. Composition of electrode coating for manual arc welding. USSR author's cert. 1540992. Int. Cl. B 23 K35/365. Publ. 1990.

13. Murzin, V.V., Russo, V.L., Evseev, V.R. et al. Electrode for manual arc welding. USSR author's cert. 15497706. Int. Cl. B 23 K35/365. Publ. 1989.

14. Pokhodnya, I.K. (1972) Gases in welds. Moscow: Mashinostroenie.

Received 24.03.2014 